\title{
EFEKTYWNOŚĆ PARTYCYPACYJNYCH INSTRUMENTÓW ZARZĄDZANIA MIASTEM
}

\section{WSTĘP}

Partycypacja społeczna zaspokaja potrzeby samorealizacji, przynależności do grupy i uznania, a więc szeroko rozumianej satysfakcji z jakości życia, o której poza stanem posiadania (dobrobyt, np. wysoka konsumpcja), coraz częściej stanowią wartości niematerialne (dobrostan), takie jak: szczęście, wolność, zdrowie, edukacja, rodzina, kontakty społeczne, praca zawodowa ${ }^{1}$.

Efektywność zarządzania miastem jako organizacji publicznej rozpatrywana musi być w wymiarze ekonomicznym i społecznym. Wymiar ekonomiczny dotyczy mierzalnych nakładów i mierzalnych efektów. Wymiar społeczny dotyczy zaś:

- szerszego zakresu oddziaływania przedsięwzięć (nakładów) na otoczenie, np.: efekty ekologiczne, edukacyjne, zdrowotne, więzi społecznych itp.;

- nakładów i efektów, które nie są wyceniane według cen rynkowych, gdyż takie ceny nie istnieją bądź nie wyrażają krańcowych kosztów i korzyści społecznych ${ }^{2}$.

Celem artykułu jest identyfikacja instrumentów partycypacyjnych w zarządzaniu miastem. Na tym tle dokonano szczegółowszej analizy jednego z instrumentów, tj. referendum lokalnego w sprawie odwołania organów samorządowych, jego podstaw prawnych, przesłanek, dynamiki i wyników.

\section{ISTOTA, ZAKRES I PODSTAWY PRAWNE PARTYCYPACJI SPOLECZNEJ W SAMORZĄDACH TERYTORIALNYCH}

Zgodnie z celem niniejszego opracowania partycypacja oznacza udział społeczności miasta w podejmowaniu decyzji politycznych i ekonomicznych oraz współpracę pomiędzy instytucjami a społeczeństwem. Podstawą takiej partycypacji jest uznanie legalności wybranej demokratycznie władzy

${ }^{1}$ T. Rostowska, Matżeństwo, rodzina, praca a jakość życia, Oficyna Wydawnicza Impuls, Kraków 2009, s. 27.

2 J. Stiglitz, Ekonomia sektora publicznego, PWN, Warszawa 2004, s. 327-356. 
i partnerstwo władz z grupami i organizacjami mieszkańców. Partycypacja w tym przypadku opiera się na założeniu, że udział obywateli w zarządzaniu publicznym nie powinien być ograniczony wyłącznie do udziału w wyborach. Obywatele sami określaja, co dla nich stanowi największy problem i w jaki sposób najlepiej go rozwiązać. Partycypacja obywatelska zaczyna się tam, gdzie władze konsultują rozwiązanie problemu z obywatelami przed podjęciem decyzji ${ }^{3}$.

Przez partycypację rozumie się udział członków organizacji w procesach decyzyjnych i w korzystaniu z efektów tych decyzji. Partycypacja jest traktowana jako forma społecznego dialogu w organizacji oraz zinstytucjonalizowany środek rozwiązywania konfliktów społecznych i wiąże się z istotną zmiana społecznej struktury organizacji, gdyż wymaga rezygnacji ze sztywnego podziału na kierujacych i kierowanych ${ }^{4}$.

Jako podstawowe, ogólne cele partycypacji w organizacji wymienia się:

- cele o charakterze psychologicznym - autonomia, samorealizacja, godność, humanizacja;

- cele społeczno-polityczne - demokratyzacja, aktywizacja, poprawa klimatu społecznego;

- cele ekonomiczne - zwiększenie wydajności, kreatywności, jakości decyzji i ich efektów ${ }^{5}$.

Celem zarządzania przez partycypację w samorządzie terytorialnym jest realizacja konstytucyjnej zasady demokracji poprzez wzrost aktywności społeczeństwa w kierunku tzw. społeczeństwa obywatelskiego. Partycypacja zaspokaja też potrzeby samorealizacji, przynależności do grupy i uznania. Z punktu widzenia interesu ekonomicznego członków społeczności lokalnej należy założyć, że jeśli partycypacja przyczynia się do wzrostu wartości zasobów lokalnych, to przyczynia się również do korzystania z tego wzrostu przez członków danej społeczności, a pracownicy sfery samorządowej korzystają wprost $\mathrm{z}$ miejsc pracy stworzonych przez samorząd w urzędzie i różnych jednostkach organizacyjnych JST.

W partycypacji społecznej w samorządach terytorialnych uwaga skupiona jest na interesie grup społecznych, a nie na interesie jednostek. W politycznym modelu podejmowania decyzji, z jakim mamy do czynienia w zarządzaniu miastem, nie ma jasnych, z góry określonych celów, gdyż są one nieustannie dyskutowane i redefiniowane przez interesariuszy, z których każdy zależnie od zajmowanej pozycji ma własna strategię. Proces decyzyjny ma charakter indukcyjny i rozpoczyna się od zadań, które ze swej istoty pojawiają się w przypadku zróżnicowanych interesów i konfliktów, a nie od ustalenia celów ${ }^{6}$.

\footnotetext{
${ }^{3}$ P. Uziębło, Demokracja partycypacyjna, Instytut Badań Społecznych, Gdańsk 2009, s. 10 i n.

${ }^{4}$ B. Błaszczyk, Uczestnictwo pracowników w zarzadzaniu przedsiębiorstwami w krajach Europy Zachodniej, PWE, Warszawa 1988, s. 22.

${ }^{5}$ J. P. Lendzion, A. Stankiewicz-Mróz, Wprowadzenie do organizacji i zarzadzania, Oficyna Ekonomiczna, Kraków 2005, s. 110.

${ }^{6}$ B. Kożuch, Zarzqdzanie publiczne. W teorii i praktyce polskich organizacji, Placet, Warszawa 2004 , s. 171.
} 
Jeśli zaś chodzi o zakres partycypacji, to jest on związany wprost ze stylem zarządzania $\mathrm{w}$ jednostce samorząu terytorialnego. Zakres ten rozpoczyna się od braku partycypacji, przy zamkniętym autokratycznym stylu zarządzania, a kończy na autonomicznym realizowaniu przez inicjatora określonych działań przy wsparciu organizacyjnym i finansowym samorządu terytorialnego odpowiedniego szczebla. Zakres ten ewoluuje od braku partycypacji, przez informowanie, konsultacje (wysłuchanie stron), współuczestnictwo, współdecydowanie, partnerską współpracę, aż po wspomaganie, np. OSP realizuje program ochrony ppoż. przy wsparciu organizacyjnym i finansowym gminy ${ }^{7}$.

Wśród powodów wprowadzania partycypacyjnych instrumentów zarządzania miastem wymienić można naciski mieszkańców, którzy robili szum medialny, zdesperowani działaniami administracji samorządowej czy rządowej, albo obowiązki wynikające z przepisów prawa krajowego i unijnego, np. przy ubieganiu się o współfinansowanie projektów rewitalizacyjnych i infrastrukturalnych ze środków unijnych.

Gmina posiada ustawowy obowiązek podejmowania działań na rzecz wspierania i upowszechniania idei samorządowej wśród mieszkańców gminy, w tym zwłaszcza wśród młodzieży. W przypadkach przewidzianych ustawą oraz w innych sprawach ważnych dla gminy mogą być przeprowadzane na jej terytorium konsultacje z mieszkańcami. Zasady i tryb przeprowadzania konsultacji z mieszkańcami określa uchwała rady gminy ${ }^{8}$.

Można więc przyjać, że partycypacja społeczna, której inicjatorem jest administracja samorządowa, powinna spełniać dwa rodzaje standardów:

- standardy prawne - najczęściej chodzi o krag organizacji i instytucji mających prawo do partycypacji, rodzaj dokumentów podlegających partycypacji, minimalny czas na jej przeprowadzenie, obowiązki organu względem uprawnionych środowisk;

- standardy pozaprawne - odnoszące się do społecznie akceptowanych, etycznych reguł dobrego organizowania wszelkiej działalności ukierunkowanej na klienta.

Zgodnie z obowiązującymi przepisami prawa wymienić można sytuacje, w których wymagane sa jakiekolwiek formy udziału społeczeństwa w zarządzaniu miastem, np.:

1) wojewoda zobowiązany jest powołać stałą konferencję współpracy gmin, powiatów i województwa, która stanowi forum wymiany informacji oraz ustalania wspólnego stanowiska, w szczególności w odniesieniu do strategii rozwoju województwa oraz regionalnych i krajowych programów operacyjnych; zarząd województwa, w przypadku regionalnych programów operacyjnych, zobowiązany jest powołać komitet monitorujący

${ }^{7}$ P. Swianiewicz, U. Klimska, A. Mielczarek, Nierówne koalicje-liderzy miejscy w poszukiwaniu nowego modelu zarzadzania rozwojem, Scholar, Warszawa 2004, s. 40-41.

8 Art. 5a i 5b ustawy z 8 marca 1990 r. o samorządzie gminnym, t.jedn.: Dz. U. 2013, poz. 594.

${ }^{9}$ Art. 7 i 8 ustawy z 6 grudnia 2006 r. o zasadach polityki rozwoju, Dz. U. Nr 227. 
2) w przypadku przystapienia do sporządzania studium uwarunkowań i kierunków zagospodarowania przestrzennego, a także miejscowego planu zagospodarowania przestrzennego - wójt/burmistrz/prezydent miasta kolejno:

- ogłasza ten fakt w prasie miejscowej oraz przez obwieszczenie;

- zawiadamia na piśmie o podjęciu uchwały instytucje i organy właściwe do uzgadniania i wydawania opinii, tj.: starostę powiatu, władze gmin sąsiednich, wojewódzkiego konserwatora zabytków, właściwe organy wojskowe, ochrony granic i bezpieczeństwa państwa, dyrektora urzędu morskiego, organ nadzoru górniczego i administracji geologicznej, ministra właściwego do spraw zdrowia, organy zarządu gospodarki wodnej oraz ochrony środowiska;

- rozpatruje złożone wnioski i sporządza projekt dokumentu;

- uzyskuje od gminnej komisji urbanistyczno-architektonicznej opinię o ww. projekcie;

- uzgadnia projekt dokumentu z zarządem województwa i z wojewoda;

- wprowadza zmiany wynikajacce z uzyskanych opinii i dokonanych uzgodnień;

- ogłasza wyłożenie projektu dokumentu do publicznego wglądu;

- wykłada projekt wraz z prognozą oddziaływania na środowisko do publicznego wglądu;

- organizuje w czasie tego wyłożenia dyskusję publiczną nad przyjętym projektem;

- wyznacza w ogłoszeniu termin wnoszenia uwag;

- przedstawia radzie gminy projekt dokumentu wraz z listą nieuwzględnionych uwag;

- przesyła wojewodzie podjętą uchwałę do zbadania jej legalności i ogłoszenia $^{10}$.

3) organ wykonawczy samorządu sporządzający program ochrony środowiska zapewnia możliwość udziału społeczeństwa w postępowaniu, którego przedmiotem jest sporządzenie tego programu; przeprowadzenia strategicznej oceny oddziaływania na środowisko wymagaja projekty programów politycznych, strategii, planów i programów w dziedzinie: przemysłu, energetyki, transportu, telekomunikacji, gospodarki wodnej, gospodarki odpadami, leśnictwa, rolnictwa, rybołówstwa, turystyki i wykorzystywania terenu - ustalajace ramy realizacji przedsięwzięć mogacych znacząco oddziaływać na środowisko ${ }^{11}$.

Partycypacją obywatelska formalnie moga być objęte wszystkie sprawy publiczne pozostajace w kompetencjach organów publicznych. Jednakże z praktycznego punktu widzenia partycypacji tej powinny podlegać w szczególności sprawy z zakresu: zagospodarowania przestrzennego, zbiorowej komunikacji publicznej, ekologii, bezpieczeństwa publicznego, strategii rozwoju, rozwiązywania problemów społecznych ${ }^{12}$.

${ }^{10}$ Art. 11 i 17 ustawy z 27 marca 2003 r. o planowaniu i zagospodarowaniu przestrzennym, t.jedn.: Dz. U. 2012, poz. 647.

11 Ustawa z 3 października 2008 r. o udostępnianiu informacji o środowisku i jego ochronie, udziale społeczeństwa w ochronie środowiska oraz o ocenach oddziaływania na środowisko, t.jedn.: Dz. U. 2013, poz. 1235.

12 Ł. Krzyżanowska, Ł. Facjejew, Partycypacja obywatelska w Polsce, Fundacja im. Stefana Batorego, Warszawa 2009, s. 46. 


\section{PROBLEM EFEKTYWNOŚCI W ZARZĄDZANIU PUBLICZNYM}

Dostarczane przez ekonomię teorie koncentrują się na ograniczonych zasobach, alokując je w alternatywne sposoby wytwarzania i dostosowując je do nieograniczonych potrzeb jednostek. Znaczenie efektywności ekonomicznej $\mathrm{w}$ podejmowaniu racjonalnych decyzji w warunkach niedoborów wynika z faktu, że nie ma nigdy wystarczających zasobów do wytworzenia dóbr i usług zaspokajających oczekiwania społeczeństwa.

Zwolennicy teorii dobrobytu wyrażaja pogląd, że alokacja ograniczonych zasobów sfery publicznej (w edukacji, ochronie zdrowia, kulturze itp.) powinna uwzględniać zasadę „każdemu według potrzeb”. Natomiast zwolennicy nowej ekonomii normatywnej uważaja, że przy alokacji zasobów należy brać pod uwagę zasadę „każdemu według możliwości” (gotowości, chęci) płacenia za określone świadczenia zdrowotne ${ }^{13}$.

Specyficzna grupę dóbr w sektorze publicznym stanowią również dobra, przy korzystaniu z których nie występuje czynnik rywalizacji, ale istnieje możliwość wykluczenia z ich konsumpcji. Wykluczenie kogokolwiek z konsumpcji dobra publicznego może być związane z ponoszeniem (lub nie) przez korzystających kosztów nazywanych w ekonomii kosztami transakcyjnymi. Tę kategorię kosztów stanowią w dużym stopniu koszty administracyjne, np. wynagrodzenie pracowników. W przypadku dóbr publicznych koszty transakcyjne mogą być bardzo wysokie, natomiast w większości dóbr prywatnych ponoszone przez konsumentów koszty transakcyjne wykluczenia mogą być stosunkowo niższe.

Wymienione czynniki rywalizacji i wykluczenia z konsumpcji dóbr publicznych prowadzą do zawodności rynku i wywierają wpływ na efektywność ekonomiczną sektora publicznego. W sektorze publicznym występują także dobra nierywalizacyjne, z których wykluczenie jest technicznie możliwe, ale nieuzasadnione z punktu widzenia efektywności ekonomicznej, np. badania diagnostyczne w służbie zdrowia. W takiej sytuacji proponowane jest wprowadzenie ceny na to dobro. Konsekwencją tej decyzji jest powstawanie bariery dostępu do tego dobra dla części potencjalnych konsumentów.

Efektywność gospodarowania w sektorze publicznym traktuje się jako ilościowa cechę działania odzwierciedlaną w relacji efektów użytkowych uzyskanych w pewnym okresie i zmierzających do zaspokojenia potrzeb odbiorcy oraz nakładów (zasobów) koniecznych do osiagnięcia tego efektu ${ }^{14}$. Z kolei efektywność organizacji publicznych rozpatruje się często od strony sprawiedliwości społecznej. W tym przypadku kładzie się nacisk na potrzeby i oczekiwania grup społecznych. Takie podejście w praktyce prowadzi do tzw. hazardu moralnego, wiązanego ze zjawiskiem nadmiernego korzystania ze świadczeń i powiązanej z nim ich nadmiernej produkcji. Ta nieuchronna

13 J. Suchecka, Ekonomia zdrowia i opieki zdrowotnej, Wolters Kluwer, Warszawa 2010, s. 71 i n.

14 A. Frączkiewicz-Wronka (red.), Pomiar efektywności organizacji publicznych na przyktadzie sektora ochrony zdrowia, Wolters Kluwer, Warszawa 2010, s. 81. 
dwuaspektowość zjawiska - aby skonsumowany mógł być nadmiar świadczeń, muszą one być uprzednio wytworzone - jest punktem wyjścia podstawowego rozróżnienia: moralnego hazardu konsumentów/świadczeniobiorców (nadkorzystanie) i moralnego hazardu wytwórców/świadczeniodawców (nadprodukcja) ${ }^{15}$.

\section{IDENTYFIKACJA I KLASYFIKACJA INSTRUMENTÓW I TECHNIK PARTYCYPACYJNYCH}

Formy udziału społeczeństwa w zarządzaniu miastem mogą być zróżnicowane i moga przybierają postac ${ }^{16}$ :

- zasięgania opinii publicznej w formie zwyczajowo przyjętej - sondaże uliczne, sondaże internetowe, ankietowanie, środki masowego przekazu;

- przedstawiania pisemnych opinii organizacji lub osób uznanych za autorytety w sprawie;

- spotkań i dyskusji z różnymi grupami społecznymi;

- uzgodnienia między instytucjami w formie wynikającej z przepisów prawa;

- zgłaszania uwag do dokumentów;

- powoływania rad obywatelskich (dzielnice osiedla, sołectwa);

- warsztatów - w grupach nominalnych, z ewentualnym udziałem ekspertów;

- konferencji - przeprowadzonych $\mathrm{w}$ gronie przedstawicieli lokalnych środowisk, władz samorządowych z dopuszczalnym udziałem ekspertów zewnętrznych;

- rozpraw administracyjnych - otwartych dla społeczeństwa, przewidzianych w art. 89 k.p.a. ${ }^{17}$

Jako nowsze formy partycypacji społecznej poza wyżej wymienionymi wyróżnić należy:

- fundusze sołeckie;

- budżety obywatelskie;

- projekty i techniki partycypacji z wykorzystaniem Internetu.

Fundusze sołeckie ${ }^{18}$ działaja w gminach posiadających sołectwa od $2009 \mathrm{r}$. Zasady tworzenia i dysponowania funduszami sołeckimi określa ustawa ${ }^{19}$. Według stanu na 31 grudnia 2011 r. w Polsce było 40540 sołectw, ale ok. 13\%

15 J. Suchecka, op. cit., s. 254 i n.

${ }^{16}$ H. Gawroński, Zarzadzanie strategiczne w samorzadach lokalnych, Wolters Kluwer, Warszawa 2010, s. 149.

${ }^{17}$ Zgodnie z art. 89 ustawy z 14 czerwca 1960 r. - Kodeks postępowania administracyjnego, t.jedn.: Dz. U. 2013, poz. 267, organ administracji powinien przeprowadzić rozprawę, gdy zachodzi potrzeba uzgodnienia interesów stron oraz gdy jest to potrzebne do wyjaśnienia sprawy przy udziale świadków lub biegłych albo w drodze oględzin. Na rozprawie strony mogą składać wyjaśnienia, zgłaszać żądania, propozycje i zarzuty oraz przedstawiać dowody, a także mogą wypowiadać się co do wyników postępowania dowodowego.

${ }_{18}$ Ponieważ zakres artykułu ogranicza się do miast, instrument ten potraktowano marginalnie.

19 Ustawa z 12 marca 2014 r. o funduszu sołeckim, Dz. U. 2014, poz. 301. 
gmin nie posiada sołectw. Z funduszy sołeckich korzysta ok. 1200 gmin, czyli co druga gmina w Polsce ${ }^{20}$.

Budżet obywatelski, zwany też budżetem partycypacyjnym, to proces decyzyjny, w ramach którego mieszkańcy współtworzą budżet danego miasta, tym samym współdecydując o dystrybucji określonej puli środków publicznych. W polskich warunkach dotyczy to ok. 0,5\% do 1\% rocznej wysokości budżetu JST. Pierwszy pełny proces tworzenia budżetu partycypacyjnego przeprowadzono w mieście Porto Alegre w Brazylii w 1989 r. ${ }^{21}$ W Polsce budżet obywatelski po raz pierwszy wprowadzono w 2011 r. w Sopocie. Obecnie wprowadzany jest w wielu miastach, m.in. w Poznaniu, Łodzi, Tarnowie, Wrocławiu, Elblągu, Gdańsku i Wodzisławiu Ślaskim. Na przykład w Elblagu w 2013 r. była to kwota 2 mln podzielona na pięć okręgów po 400 tys. zł, a w 2014 r. wydzielono dodatkowo kwotę $0,5 \mathrm{mln}$ na zadania ogólnomiejskie ${ }^{22}$.

Budżet obywatelski nie jest instytucja określoną w prawie finansów publicznych. Wciąż pozostaje aktualna zasada, że budżet przygotowuje organ wykonawczy, czyli wójt (burmistrz, prezydent miasta) ${ }^{23}$. Organ wykonawczy w ramach swoich kompetencji może, w drodze zarządzenia, określić sposób przygotowania projektu budżetu, w tym zasady zgłaszania i weryfikacji wniosków do części budżetu nazywanego budżetem obywatelskim.

Wdrożeniem budżetu partycypacyjnego jako elastycznego, politycznie neutralnego narzędzia, które dzięki otwartym spotkaniom mieszkańców skutecznie podnosi efektywność realizacji dotychczasowej, odgórnie ustalonej polityki miejskiej, a także:

- skutecznie ją legitymizuje wśród mieszkańców;

- promuje innowacyjność i przedsiębiorczość;

- pozwala wraz z mieszkańcami podejmować trudne, kontrowersyjne decyzje;

- pozwala uzyskać od mieszkańców szereg informacji o funkcjonowaniu miasta;

- wspiera proces decentralizacji władzy; cami;

- jest odpowiedzią na rosnący dystans pomiędzy rządzącymi i mieszkań-

- buduje zaufanie mieszkańców do samorządu i jego przedstawicieli;

- potencjalnie zwiększa popularność polityków, którzy się w nią angażują ${ }^{24}$.

Wśród wybranych projektów i technik partycypacji z wykorzystaniem Internetu wskazać należy te, które już obecnie mogą być traktowane jako dobre praktyki. Sa to m.in. projekty:

- Laboratorium Partycypacji Obywatelskiej!

- Demokracja w Działaniu!

- Elblag Konsultuje!

${ }^{20}$ Maty Rocznik Statystyczny Polski 2012, GUS, Warszawa 2012, s. 82.

${ }^{21}$ M. Gerwin, M. Grabkowska: Budżet obywatelski, w: Partycypacja. Przewodnik Krytyki Politycznej, Warszawa 2012, s. 100.

${ }_{22}$ Zob. http://www.budzetobywatelski.elblag.eu/ (dostęp: 14.05.2014).

${ }^{23}$ Ustawa z 27 sierpnia 2009 r. o finansach publicznych, t.jedn.: Dz. U. 2013, poz. 885.

${ }^{24}$ W. Kębłowski, Budżet partycypacyjny. Krótka instrukcja obstugi, Instytut Obywatelski, Warszawa 2013, s. 9-14. 
Projekt: Laboratorium Partycypacji Obywatelskiej - zrealizowany został przez Pracownię Badań i Innowacji Społecznych „Stocznia” przy wsparciu Fundacji im. Stefana Batorego. Laboratorium powstało jako miejsce służące wymianie wiedzy i doświadczeń różnorodnych środowisk oraz osób związanych z działaniami partycypacyjnymi. W ramach projektu uruchomiono portal Partycypacjaobywatelska.pl. Organizatorzy portalu organizuja seminaria i warsztaty z zakresu partycypacji społecznej. Rozbudowywana jest zakładka prezentująca nowe techniki i formy partycypacji społecznej w praktyce zastosowane w różnych samorządach, takie jak: 21st Century Town Meeting, Future City Game, World Cafe, kawiarnie, narady, panele i sądy obywatelskie, inicjatywy otwartej przestrzeni, sondaże deliberatywne, spacery badawcze, warsztaty przyszłościowe ${ }^{25}$.

Projekt: Demokracja w Działaniu - zrealizowany przez Fundację im. Stefana Batorego oraz Laboratorium EE i Pracownię Badań i Innowacji Społecznych „Stocznia”. Efektem realizacji projektu jest uruchomienie serwisu internetowego Naprawmyto.pl. Umożliwia on mapowanie i zgłaszanie problemów $\mathrm{w}$ przestrzeni publicznej wymagajacych interwencji, czyli „naprawienia”. Serwis umożliwia zgłaszanie problemów w przestrzeni publicznej zaobserwowanych w najbliższym otoczeniu. Zgłoszenia można dokonać przez stronę internetową lub aplikację na urządzenia mobilne. Każde zgłoszenie jest rejestrowane w systemie, a odpowiedni komunikat przekazywany do instytucji odpowiedzialnych za dany problem, np.: dziury w drogach, niedziałajace światła, nieuprzątnięte śmieci, doświetlanie niebezpiecznych miejsc, wylewanie cieków, powalone drzewa, martwe zwierzęta itp. ${ }^{26}$

Projekt: Elblag Konsultuje - finansowany jest z PO Kapitał Ludzki, a realizowany jest przez Elblaskie Stowarzyszenie Wspierania Inicjatyw Pozarzadowych (ESWIP). Partnerem projektu jest Gmina Miasto Elblag oraz Rada Elbląskich Organizacji Pozarządowych ${ }^{27}$. Celem projektu jest wzrost efektywności konsultacji społecznych organizowanych przez Gminę Miasto Elblag. Zakłada się, że w ramach projektu:

- w urzędzie miasta nastapi wzrost poziomu wiedzy i umiejętności w zakresie nowoczesnych, skutecznych konsultacji społecznych z udziałem mieszkańców i organizacji pozarządowych;

- zwiększy się aktywność mieszkańców i organizacji w konsultacjach;

- rozszerzy się katalog metod konsultacyjnych, w tym z zastosowaniem Internetu.

Istotnym elementem i jednocześnie narzędziem projektu „Elblag Konsultuje!" ma być wdrożenie platformy online. Projekt zakłada udział w dialogu użytkowników posiadających zarejestrowane konto. Zalogowany użytkownik ma mieć wgląd w proces konsultacji z możliwością udziału w debacie. Użytkownik, który nie posiada konta, ma możliwość wglądu w tematy, materiały, pytania i udzielone odpowiedzi. Na platformie znajdą się: konta użytkowników, system komentarzy, kwestionariusze online, fora dyskusyjne; pozwoli ona na

\footnotetext{
25 Zob. http://partycypacjaobywatelska.pl (dostęp: 10.04.2014).

26 Zob. http://naprawmyto.pl (dostęp: 16.04.2014).

27 Zob. http://elblagkonsultuje.pl (dostęp: 20.04.2014).
} 
oznaczanie miejsc na mapie, generowanie osi czasu, da możliwość osadzenia infografik, zawierać będzie również system banerów reklamowych z możliwością nadania uprawnień innym użytkownikom do poszczególnych modułów.

Prezydencki projekt ustawy zakłada wprowadzenie nowych form konsultacji ${ }^{28}$ :

- wysłuchania publicznego jako szczególnej formy konsultacji społecznych - w celu uzyskania opinii mieszkańców gminy o projekcie uchwały rady gminy w sprawach projektów: statutu gminy, uchwały budżetowej, uchwał w sprawie planowania rozwoju;

- prawo obywatelskiej inicjatywy uchwałodawczej.

Prawo obywatelskiej inicjatywy uchwałodawczej nie jest dotychczas uregulowane. Organy nadzoru (wojewodowie) dotychczas bardzo zróżnicowanie reagowały na próby wprowadzania tego narzędzia w statutach miast. Zdaniem NSA prawo do przyznania inicjatywy uchwałodawczej grupie mieszkańców należy łączyć z definicją wspólnoty samorządowejej ${ }^{29}$. Celem tej inicjatywy jest wzmocnienie podstaw do współpracy mieszkańców, podejmowanej w celu rozwoju lokalnego i regionalnego. W odróżnieniu od innych form (spotkania z radnymi, postulaty i projekty mieszkańców) inicjatywa obywatelska nakłada na radę miejską obowiązek zajęcia się ważnymi kwestiami. Przedmiotem inicjatywy obywatelskiej może być każda sprawa wchodząca w zakres działania i zadania gminy oprócz zastrzeżonych do wyłącznej inicjatywy organu wykonawczego, np. projekt uchwały budżetowej w JST, choć i tu można znaleźć partycypacyjne rozwiązanie - patrz budżet obywatelski.

Inicjatywa lokalna łączy w sobie dwa wymiary obywatelskiego zaangażowania: partycypację (współudział) oraz aktywizowanie społeczności lokalnych w realizację zadań publicznych odpowiadających na ich zbiorowe zapotrzebowanie. Inicjatywa taka jest swoistym przymierzem postaw obywatelskich zwykłych mieszkańców oraz otwartości władz na społeczność i jej zaangażowanie ${ }^{30}$.

\section{REFERENDUM LOKALNE W SPRAWIE PRZEDTERMINOWEGO ODWOLANIA ORGANÓW JST}

Podstawa prawna przeprowadzania referendum lokalnego w Polsce jest Konstytucja RP, która w art. 170 stanowi, że: „Członkowie wspólnoty samorządowej mogą decydować, w drodze referendum, o sprawach dotyczących tej wspólnoty, w tym o odwołaniu pochodzącego z wyborów bezpośrednich orga-

${ }^{28}$ Projekt ustawy o współdziałaniu w samorządzie terytorialnym na rzecz rozwoju lokalnego i regionalnego oraz o zmianie niektórych ustaw; druk nr 1699, http://www.sejm.gov.pl/sejm7.nsf/ PrzebiegProc.xsp?nr=1699 (dostęp: 5.02.2014).

${ }^{29}$ Wyrok NSA z 21 listopada 2013 r., sygn. akt II OSK 1887/13, http://www.samorzad.lex. $\mathrm{pl} /$ czytaj/-/artykul/nsa-statut-gminy-moze-przyznawac-inicjatywe-uchwalodawcza-mieszkancom (dostęp: 5.02.2014).

${ }^{30}$ A. Czarkowska et al., Inicjatywa lokalna. Krok po kroku, Wydawca Sieć SPLOT, Warszawa 2013, s. 11 i n. 
nu samorządu terytorialnego" ${ }^{31}$. Referendum lokalne przeprowadza się z inicjatywy organu stanowiącego lub na wniosek mieszkańców uprawnionych do głosowania w liczbie: 10\% mieszkańców gminy lub powiatu, 5\% mieszkańców województwa. Referendum jest ważne, jeżeli frekwencja wynosi 30\%, a w przypadku odwołania organu JST pochodzącego z wyborów bezpośrednich, minimalna frekwencja wynosi 3/5 liczby osób biorących udział w wyborze odwoływanego organu ${ }^{32}$.

W sprawach odwołania organu stanowiacego JST (rady gminy, miasta, powiatu, sejmiku samorządowego) przed upływem kadencji, co do zasady, rozstrzyga się wyłącznie w drodze referendum przeprowadzonego na wniosek mieszkańców ${ }^{33}$.

Pierwsze referenda lokalne w III RP odbyły się w 1 marca 1992 r. Referenda te dotyczyły odwołania Rady Gminy Józefów w byłym woj. warszawskim oraz Rady Gminy Przybiernów w byłym woj. szczecińskim. Analizę ilościową referendów lokalnych w przedmiotowej sprawie w poszczególnych latach przedstawia tabela.

$\mathrm{Na}$ podstawie danych tabeli oraz na podstawie innych informacji pochodzacych ze źródeł Państwowej Komisji Wyborczej ${ }^{34}$ można stwierdzić, że:

- inicjatywa referendum lokalnego w sprawie przedterminowego odwołania władz JST jest swoistą wiarą w siłę demokracji; nie można jednak stwierdzić, że referendum takie jest zwycięstwem demokracji, potwierdza bowiem jedynie, że wyborcy pomylili się we wcześniejszym swoim wyborze, a teza ta dotyczy jedynie referendów skutecznych;

- referendum takie jest raczej reakcją na kryzys władzy, swoistym wotum nieufności;

- liczba referendów w sprawie przedterminowego odwołania organów JST w kolejnych latach i województwach jest zróżnicowana i trudno tu jednoznacznie wskazać tendencję rosnąca;

- ilość referendów jest raczej związana z kalendarzem wyborczym; w okresach pomiędzy wyborami do organów władz samorządowych najwięcej referendów odbywało się w trzecim roku każdej kadencji, co wydaje się dość logiczne, ponieważ w okresach wyborczych aktywność w zakresie demokracji bezpośredniej przenoszona jest na kampanie wyborcze;

- w dotychczasowej historii referendów lokalnych w III RP najwięcej referendów - 108 odbyło się w 2000 r., czyli w pierwszej kadencji po drugim etapie reformy administracyjnej i utworzeniu powiatów i województw samorządowych;

- obserwuje się nieznaczną tendencję rosnącą w trendzie ważności referendów, szczególnie od 2007 r., co można tłumaczyć coraz lepszym przygotowaniem inicjatyw referendalnych;

- obserwuje się też wzrost skuteczności referendów lokalnych, tzn. że odpowiednio coraz więcej organów zostaje odwołanych ze swojej funkcji w drodze referendum;

\footnotetext{
${ }^{31}$ Konstytucja Rzeczypospolitej Polskiej z 2 kwietnia 1997 r., Dz. U. Nr 78, poz. 483.

32 Ustawa z 15 września 2000 r. o referendum lokalnym, t.jedn.: Dz. U. 2013, poz. 706.

${ }^{33}$ Zgodnie z art. 96 ustawy z 8 marca 1990 r. o samorządzie gminnym (t.jedn.: Dz. U. 2013, poz. 594) radę gminy może także rozwiązać Sejm RP na wniosek Prezesa RM w przypadku powtarzającego się naruszania przez radę gminy Konstytucji lub ustaw.

34 Zob. www.pkw.gov.pl (dostęp: 9.06.2014).
} 


\section{Tabela}

\begin{tabular}{|c|c|c|c|}
\hline \multirow{2}{*}{ Lp. } & \multirow{2}{*}{ Rok } & \multicolumn{2}{|c|}{ Liczba referendów } \\
\hline & & ogółem & w tym: ważne \\
\hline 1. & 1992 & 23 & 0 \\
\hline 2. & 1993 & 25 & 3 \\
\hline 3. & 1994 - rok wyborczy & 5 & 0 \\
\hline 4. & 1995 & 35 & 1 \\
\hline 5. & 1996 & 31 & 5 \\
\hline 6. & 1997 & 33 & 3 \\
\hline 7. & 1998 - rok wyborczy & \multicolumn{2}{|c|}{ Referenda gminne nie odbywały się } \\
\hline 8. & 1999 & 15 & 4 \\
\hline 9. & 2000 & 108 & 12 \\
\hline 10. & 2001 & 70 & 7 \\
\hline 11. & 2002 - rok wyborczy & 3 & 0 \\
\hline 12. & 2003 & 3 & 0 \\
\hline 13. & 2004 & 57 & 9 \\
\hline 14. & 2005 & 30 & 2 \\
\hline 15. & 2006 - rok wyborczy & 2 & 0 \\
\hline 16. & 2007 & 3 & 2 \\
\hline 17. & 2008 & 36 & 6 \\
\hline 18. & 2009 & 32 & 4 \\
\hline 19. & 2010 - rok wyborczy & 10 & 1 \\
\hline 20. & 2011 & \multicolumn{2}{|c|}{ Nie odbyło się żadne referendum } \\
\hline 21. & 2012 & 61 & 9 \\
\hline 22. & 2013 & 57 & 10 \\
\hline 23. & 2014 - rok wyborczy & 4 & 1 \\
\hline
\end{tabular}

Źródło: opracowanie własne na podstawie danym PKW, www.pkw.gov.pl (dostęp: 9.06.2014).

- w latach 2007-2014 - na 203 referenda odwołano 33 organy, w tym 7 rad gminnych;

- wszystkie dotychczasowe referenda dotyczyły organów gminy, w tym w ok. $30 \%$ dotyczyły one organu stanowiącego (rady), a w ok. $70 \%$ dotyczyły tylko organu wykonawczego, albo organu wykonawczego i rady jednocześnie;

- żadne referendum nie dotyczyło organów stanowiących powiatu ani województwa;

- prawie wszystkie przypadki (poza jednym), w których referendum było ważne, jednocześnie było też skuteczne, tzn. organ, którego dotyczyło referendum, został odwołany;

- jedyny przypadek, w którym referendum było ważne, ale nieskuteczne, tzn. organ nie został odwołany, dotyczy referendum w sprawie odwołania prezydenta Miasta Sopotu, w którym przy ponad 40\% frekwencji większość 
mieszkańców (ok. 61\%) opowiedziała się za pozostawieniem prezydenta Jacka Karnowskiego na stanowisku do końca kadencji.

Wśród miast, w których odbyły się referenda w sprawie odwołania władz, są np.: Łódź, Bytom czy Elbląg, a więc miasta, które „przegrały” transformację ustrojowa. W takich miejscach ujawnia się zahibernowana przez ostatnia dekadę niechęć Polaków do transformacji, niezadowolenie z jej kierunku, co widać w różnych badaniach. Wszyscy żyjemy mitem sprawnego, skutecznego samorządu, który dokonał niesamowitych inwestycji w ostatniej dekadzie. Tymczasem teraz powoli zaczynamy sobie zdawać sprawę, że te inwestycje nie są za darmo, że ich utrzymanie będzie dużo kosztowało i że w wielu przypadkach należy zadać pytanie o sensowność tego typu inwestycji ${ }^{35}$.

W samorządach, w których dochodziło do referendów w sprawie przedterminowego odwołania władz, występowały też na ogół zauważalne objawy patologii biurokracji (wg Kieżuna) ${ }^{36}$, tj.: gigantomanii (nadmiernie rozbudowane, nietransparentne struktury organizacyjne, patetyczne nazewnictwo); luksusomanii (kosztowne utrzymanie personelu i wyposażania biur), korupcji, nepotyzmu, podziałów na „równych i równiejszych” oraz tzw. arogancji urzędniczej. To rodziło zniecierpliwienie społeczności lokalnych i swoistą niechęć do niedawno wybranych organów takiej władzy i prowokowało do wszczynania procedury ich odwołania. Zjawiska te upowszechniane w lokalnych mediach dodatkowo potęgowały negatywną opinię społeczną o władzy lokalnej.

\section{WNIOSKI}

Instrumenty partycypacji społecznej w samorządach nie zastępują mechanizmów demokracji, a wręcz przeciwnie, sąich uzupełnieniem. Ich konieczność wynika z niedostatków procedur demokratycznych, do których można zaliczyć m.in.: niepełny mandat legitymizacji rządzących (niska frekwencja i „wygrani biorą wszystko"), konieczność określania priorytetów przy niedoborze środków publicznych, niewystarczające mechanizmy reprezentacji interesów (komisje, rady, komitety itp.), coraz powszechniejsze referenda za odwołaniem władz, konieczność konsensusu w umowach społecznych, brak równowagi przywilejów społecznych w stosunku do zobowiązań wobec samorządu.

Istota i sens partycypacji polegają na tym, że w jej efekcie dochodzi do mikroporozumień pomiędzy władzą a społeczeństwem, co jest dalszą zachęta, aby społeczeństwo chciało się umawiać z władza, a nie tylko odwoływać ja w referendum. Przez partycypację realizuje się idea dobrego rządzenia jako procesu.

Zagrożeniem dla partycypacji może być skłonność uczestników partycypacji do lobbowania pod sztandarami demokracji za realizacją partykularnych interesów dotyczących wąskiej grupy osób. Chodzi więc o to, aby sięgnąć po opinię

${ }^{35}$ R. Chwedoruk, z wywiadu dla PAP, http://www.samorzad.lex.pl/czytaj/-/artykul/politolog-referenda-lokalne-sa-reakcja-na-kryzys (dostęp: 13.08.2013).

${ }^{36}$ W. Kieżun, Sprawne zarzadzanie organizacja. Zarys teorii i praktyki, SGH, Warszawa 1998 , s. 377. 
tych, którzy sami się nie ujawnią i nie odezwą. Temu celowi mógłby służyć tzw. panel obywatelski. Jego organizacja polegałaby na tym, aby za pomoca metod socjologicznych dobrać w mieście stosunkowo szeroką próbę badawczą osób, która byłaby reprezentatywna dla danego społeczeństwa. Ta próba badawcza stanowiłaby środowisko opiniodawcze względnie obiektywne i niezależne. Istotne problemy występują jednak z ustaleniem, doborem i utrzymaniem takiej próby badawczej, chociażby ze względu na ruchy demograficzne.

W konkluzji analizy efektywności sektora publicznego należy stwierdzić, że ze względu na ekonomiczną ograniczoność zasobów publicznych możliwe sa jedynie trzy metody reglamentacji dóbr dostarczanych przez sektor publiczny, a mianowicie opłaty za użytkowanie, zaopatrzenie „po równo” albo kolejki. Każda z tych metod ma istotne wady. Jednakże ze względu na zjawisko tzw. hazardu moralnego w żadnym systemie nie ma możliwości zabezpieczenia i zaspokojenia pełnych potrzeb społecznych ze środków publicznych. Inaczej mówiąc, nigdy nie nastapi pełne zaspokojenie usług społecznych, np. w dziedzinie ochrony zdrowia, edukacji publicznej, komunikacji publicznej.

$\mathrm{W}$ inicjowaniu referendów lokalnych istotna jest kwestia wiarygodności argumentów stanowiacych podstawę dyskredytacji dotychczasowych władz. Rozwój technologii informatycznych i dostęp do Internetu pozwalają na odbiór i nadawanie praktycznie nieograniczonej ilości informacji. Problemem społecznym staje się tu selekcja informacji i odróżnienie informacji wartościowych i obiektywnych od niewartościowych, czy wręcz wprowadzających w błąd.

Inicjatorzy referendów lokalnych kierowali się raczej doraźnymi emocjami wywoływanymi np. zwiększoną egzekucją należności czynszowych za lokale i mieszkania komunalne, utrudnieniami w płynności ruchu ulicznego w zwiąku z robotami modernizacyjnymi w ciagach komunikacyjnych, czy choćby zapowiadanym wzrostem cen biletów komunikacji miejskiej. Nie przedstawiali oni alternatywnych rozwiązań, nie proponowali programów lepszych od dotychczas realizowanych. Skupiali jedynie wysiłek na konsolidacji głosów osób niezadowolonych, również tych pozostających wobec siebie w skrajnej opozycji.

Stabilność władz lokalnych jest warunkiem efektywnego rozwoju. Poza wydatkami finansowymi związanymi z referendum, które można byłoby przeznaczyć na inne cele, np. poprawę infrastruktury, powoduje ono zahamowanie procesów rozwojowych, dezorganizację decyzyjna, a kampanie referendalno-wyborcze zawsze powodują zaostrzenie podziałów społecznych, co nie sprzyja budowaniu integracji ani zakorzenieniu społecznemu, ani też pozytywnemu wizerunkowi samorządu na zewnątrz.

Z drugiej strony partycypacyjny model zarzadzania miastem zwiększa społeczne zaangażowanie i odpowiedzialność za decyzje podejmowane na poziomie lokalnym. A to z kolei przekłada się na bardziej skuteczne i efektywne działania samorządów oraz wpływa na wzrost społecznego poparcia dla wybranych przedstawicieli.

dr Henryk Gawroński

Państwowa Wyższa Szkoła Zawodowa w Elblagu

h.gawronski@pwsz.elblag.pl 


\section{EFFICIENCY OF PARTICIPATORY INSTRUMENTS OF CITY MANAGEMENT}

\section{Sum mary}

The purpose of this study is to identify the instruments of participation in city management. Against this background, a careful analysis has been carried out on the local referendum on the subject of appeals to local government bodies, their legal basis, rationale, dynamics and performance.

Social participation meets the needs of self-fulfilment, belonging and recognition. The effectiveness of urban management as a public organization must be considered in economic and social terms. The economic dimension refers to measurable inputs and measurable results. The social dimension refers to the broader impact on the surrounding area such as the effect on the environment, education and health, and on social ties. 